\title{
Report on Notifications Pursuant to $\$ 21$ German Transfusion Act for 2008 and 2009
}

\author{
Olaf Henseler Margarethe Heiden Birgit Haschberger Janina Hesse Rainer Seitz
}

Paul-Ehrlich-Institut, Bundesinstitut für Impfstoffe und biomedizinische Arzneimittel, Langen, Germany

\author{
Keywords \\ Blood donations - Erythrocyte concentrates . \\ Plasma for fractionation - Blood coagulation factors . \\ Supply situation
}

\section{Summary}

This report contains the data collected in 2008 and 2009, pursuant to Section 21 German Transfusion Act as well as an overview of the supply situation during the last 10 years. In 2009, blood donation services reported a total of 7.5 million donations - the largest amount since 2000. At the same time, more than 4.7 million red blood cell (RBC) concentrates and more than 500,000 platelet concentrates were available. The number of therapeutic single plasma units decreased to 1.1 million units in 2009. The loss rate for RBC concentrates is still between 3 and $4 \%$ for the users while for the manufacturers it has decreased slightly to $1.4 \%$. The loss rate, for platelet concentrates, on the other hand, increased in 2009, especially- what is noteworthy -for manufacturers of pooled platelet concentrates. The loss rate for apheresis platelet concentrates accounted for $5.2 \%$ compared to $17.5 \%$ for pooled platelet concentrates. As far as the users were concerned, loss rates for platelet concentrates largely remained unchanged with rates between 5 and $6 \%$. Based on the data collected, the supply with blood components for transfusion can be regarded as assured. Nearly 2.9 million I of plasma for fractionation were collected in Germany in 2009. According to reports from the pharmaceutical industry, out of these, 2.6 million I remained on the German market, out of which only $56 \%$ were fractionated in this country. Many plasma derivatives are not manufactured in Germany, despite the large amounts of plasma collected. The supply with these products, however, is assured by imports. Overall, 16,409 autologous and 9,435 allogeneic stem cell preparations were manufactured in 2009 , out of which 3,382 allogeneic preparations were exported. 3,181 autologous and 2,374 allogeneic preparations were transplanted; 187 of these products from imports. The large number of exported stem cells and the small number of imported ones suggest that no serious shortages are to be expected for the supply with these products.

\section{KARGER}

Fax +497614520714

Information@Karger.de

www.karger.com (c) 2011 S. Karger GmbH, Freiburg

Accessible online at:

www.karger.com/tmh
Schlüsselwörter

Blutspenden · Erythrozytenkonzentrate ·

Plasma zur Fraktionierung · Gerinnungsfaktoren .

Versorgungslage

\section{Zusammenfassung}

Dieser Bericht enthält die nach §21 Transfusionsgesetz erhobenen Daten der Jahre 2008 und 2009 sowie Auswertungen zur Versorgungssituation im Verlauf der letzten 10 Jahre. Die Blutspendedienste meldeten im Jahr 2009 insgesamt 7,5 Millionen Spenden - die größte Zahl seit dem Jahr 2000. Damit einhergehend wurden auch mehr Erythrozytenund Thrombozytenkonzentrate (EK, TK) hergestellt; jeweils über 4,7 Millionen EK und mehr als 500000 TK standen 2008 und 2009 zur Verfügung. Die Zahl der therapeutischen Einzelplasmen ist wieder gesunken auf 1,1 Millionen Einheiten im Jahr 2009. Die Verfallsrate von EK bei den Anwendern liegt nach wie vor zwischen 3 und $4 \%$, bei den Herstellern ist sie leicht gesunken auf 1,4\%. Dagegen stieg die Verfallsrate bei den TK, besonders auffällig bei den Herstellern von Pool-TK im Jahr 2009. Einem Verfallsanteil von 5,2\% der Apherese-TK standen 17,5\% verfallene Pool-TK gegenüber. Bei den Anwendern verfielen weitgehend unverändert zwischen 5 und 6\% der TK. Auf Basis der erhobenen Daten kann die Versorgung mit Blutkomponenten zur Transfusion als gesichert angesehen werden. Fast 2,9 Millionen I Plasma zur Fraktionierung wurden 2009 in Deutschland gesammelt. Laut den Meldungen der pharmazeutischen Industrie verblieben davon rund 2,6 Millionen I auf dem deutschen Markt, wovon lediglich 56\% hierzulande verarbeitet wurden. Über den Verbleib der restlichen Menge kann keine Aussage getroffen werden. Viele Plasmaderivate werden, trotz der großen Menge zur Verfügung stehenden Plasmas, nicht in Deutschland hergestellt. Die Versorgung mit diesen Produkten ist jedoch durch Importe gewährleistet. Insgesamt 16409 autologe und 9435 allogene Blutstammzellpräparate wurden 2009 hergestellt, davon wurden 3382 allogene Präparate exportiert. Transplantiert wurden 3181 autologe und 2374 allogene Präparate; 187 davon kamen aus dem Ausland. Die große Zahl exportierter Stammzellen und die wenigen importierten Präparate lassen auch bei diesem Produkt keine gravierenden Versorgungsengpässe erwarten. 


\section{Introduction}

The blood donation services, the pharmaceutical industry, and the health care facilities provide the Paul-Ehrlich-Institut (PEI) with annual data on the extent of the collection of blood and blood components, the manufacture, imports, and exports as well as the loss and expiry of blood products and recombinant plasma proteins for the treatment of haemostasis disorders. In the meantime, data are available from the past 10 years. In addition to the documentation of the current supply situation, these data can be used to derive trends on the provision of blood products in Germany. The results are also published on the PEI website [2] in tabular form and updated regularly. The figures published on that website can therefore deviate from the figures provided in this report.

\section{Methodology}

\section{Report Forms}

Notifications are submitted exclusively by means of a web application, the online reporting system pursuant to Section 21 Transfusionsgesetz (TFG; German Transfusion Act).

Information on the Collection of Blood and Blood Products

This information comprises the number of collections of allogeneic and autologous blood including plasma as the starting material for fractionation as well as haematopoietic stem cells (HSC). Since 2009, the collection of HSC from bone marrow is also recorded here.

\section{Information on the Manufacture, Consumption, Loss and Expiry}

This information includes manufacture, imports, exports (including country of origin and country of export), consumption, loss and expiry of blood components, HSC, medicinal products derived from human plasma, and recombinant coagulation factor products.

\section{Information on Patients with Congenital Haemostasis Disorders}

Since the reporting year 2008, data on patients with congenital haemostasis disorders requiring treatment pursuant to Section 21 TFG are collected via the German Haemophilia Register (DHR) [3]. This data is still incomplete because the DHR has only been introduced recently. They will be published in the next report. The data include the number of patients with haemophilia A and B categorised by seriousness of the disorder and age group, the number of patients with von Willebrand's disease as well as the total of the products administered to these groups of individuals.

\section{Facilities for Which Reporting Is Compulsory}

Manufacturers of blood products and recombinant plasma proteins for the treatment of haemostasis disorders as well as health care facilities consuming blood products are required to report pursuant to Section 21 TFG.

Donor facilities are classified as follows:

- Blood donation services of the German and the Bavarian Red Crosses: As a rule, the institutes of the Red Cross operate independently from hospitals. They not only organise blood donations on a large scale but also the provision of the blood components manufactured from these donations. They have the company structure of a non-profit $\mathrm{GmbH}$ (limited liability company).
- State, local authority, non-commercial and private blood donation services at hospitals: Apart from local authority blood donation services, these also include donation facilities at university hospitals and at noncommercial or (in the meantime) privatised hospitals.

- Private donation centres: Private donations centres are blood donation services and plasmapheresis centres in the corporate form of a $\mathrm{GmbH}$ or AG (public limited company) not operating on a charitable basis and, as a rule, not run by the responsible body of hospitals.

- Plasma processing / pharmaceutical companies: This category comprises pharmaceutical enterprises that manufacture, import, or export coagulation factors or other medicinal products from blood plasma as well as recombinant coagulation factor products or sell such products in Germany.

- Bundeswehr (German Army): The Army maintains its own blood donation service to provide the soldiers with blood components.

Health care organisations which consume blood products are classified as follows:

- Clinics and hospitals providing basic, regular, focused or maximum care.

- Panel doctors, dialysis centres, and outpatient clinics.

- Health-care facilities of the German Army.

- 'Other medical institutions', comprising rheumatology centres, rehabilitation centres, geriatric, and psychiatric facilities.

The above mentioned institutions are required to report the number of blood components transfused, the number of HSC transplanted, and the administration of plasma proteins.

\section{Results and Discussion}

\section{Reporting Rates}

For 2008, the overall response rate was $81 \% .2,300$ institutions transmitted their figures in 2009 , which is equivalent to around $80 \%$ of the institutions registered at the PEI as required to report.

\section{Collection and Manufacture}

As in previous years, all blood donation facilities in Germany transmitted their figures. Thus, reliable data are available on the amount of blood components available for transfusion in Germany. Data are missing only on the facilities performing autologous blood collection and on the plasma-processing industry (table 1).

The number of facilities in which pre-operative autologous blood is donated steadily declined from originally 597 to only 241 facilities in 2009.

\section{Consumption}

In 2009, altogether 2,299 reports, corresponding to $80 \%$ of the facilities registered at the PEI were received from facilities using blood products. The response rate thus rose by $7 \%$ compared with 2007. This means, however, that more than 500 health care facilities still do not report their consumption of blood products (table 2 ).

\section{Collection of Blood and Blood Components}

In 2008, more than 7.12 million allogeneic blood donations were provided by donors in Germany corresponding to an increase of $7.2 \%$ compared with the previous year. The portion 
Table 1. Response from the manufacturers (collection, production, imports, and exports)

\begin{tabular}{|c|c|c|c|}
\hline \multirow{2}{*}{$\begin{array}{l}\text { Type of organisation } \\
2008\end{array}$} & \multirow{2}{*}{$\begin{array}{l}\text { Number of } \\
\text { manufacturers }\end{array}$} & \multicolumn{2}{|c|}{ Notifications } \\
\hline & & & \\
\hline State-run, municipal or private hospitals, non-profit limited liability company & 57 & 57 & $(100 \%)$ \\
\hline Red Cross & 9 & 9 & $(100 \%)$ \\
\hline Plasma processing industry & 16 & 14 & $(88 \%)$ \\
\hline Private donation centre & 10 & 10 & $(100 \%)$ \\
\hline German Army & 1 & 1 & $(100 \%)$ \\
\hline $\begin{array}{l}\text { Facilities collecting autologous blood, manufacturing blood components from } \\
\text { directed donations or haematopoietic stem cell preparations }\end{array}$ & 322 & 295 & $(92 \%)$ \\
\hline Total & 415 & 386 & $(93 \%)$ \\
\hline \multicolumn{4}{|l|}{2009} \\
\hline State-run, municipal or private hospitals, non-profit limited liability company & 55 & 55 & $(100 \%)$ \\
\hline Red Cross & 9 & 9 & $(100 \%)$ \\
\hline Plasma processing industry & 18 & 17 & $(94 \%)$ \\
\hline Private donation centre & 13 & 13 & $(100 \%)$ \\
\hline German Army & 1 & 1 & $(100 \%)$ \\
\hline $\begin{array}{l}\text { Facilities collecting autologous blood, manufacturing blood components from } \\
\text { directed donations or haematopoietic stem cell preparations }\end{array}$ & 302 & 269 & $(89 \%)$ \\
\hline Total & 398 & 364 & $(91 \%)$ \\
\hline
\end{tabular}

Table 2. Response from the users (consumption)

\begin{tabular}{lcrc}
\hline Type of organisation & $\begin{array}{l}\text { Number of } \\
\text { manufacturers }\end{array}$ & Notifications & \\
\hline 2008 & & & \\
Hospital & 1,672 & 1,437 & $(86 \%)$ \\
Panel doctors / dialysis centres / surgery & 1,045 & 797 & $(76 \%)$ \\
German Army & 1 & 1 & $(100 \%)$ \\
Other medical facilities & 153 & 77 & $(50 \%)$ \\
Total & 2,871 & 2,312 & $(81 \%)$ \\
\hline 2009 & 1,666 & 1,422 & $(85 \%)$ \\
Hospital & 1,043 & 789 & $(76 \%)$ \\
Panel doctors / dialysis centres / surgery & 1 & 1 & $(100 \%)$ \\
German Army & 154 & 87 & $(56 \%)$ \\
Other medical facilities & 2,864 & 2,299 & $(80 \%)$ \\
Total & & & \\
\hline
\end{tabular}

of whole blood donations amounted to $68 \%$. In 2009, the German population was even more motivated to donate. More than 7.42 million allogeneic blood donations could be recorded - an increase of $4.2 \%$ compared with 2008 . The donations were voluntary and gratuitous; expenses associated with blood donations are often compensated conforming to the laws [1, 4].

Whole blood donations form the basis for the supply with blood products, not only for blood components for transfusion but also for plasma for fractionation as the starting product for the manufacture of medicinal products from human plasma. In 2008, the number of whole blood donations rose by $2.2 \%$ compared to 2007 accounting for 4.81 million. Again, in 2009, a slight increase by $1.1 \%$ to 4.86 million could be recorded compared with the previous year (table 3 , fig. 1 ).
Since 2000, the number of preoperative autologous blood collections declined from 216,000 to 48,000 collections in 2009. The portion of autologous blood collections compared with the total number of whole blood donations thus declined from $4.7 \%$ to just below $1 \%$ (table 4 , fig. 1 ). Such a downward trend can also be observed in the member states of the Council of Europe. The current report form 2006 shows a medium portion of autologous blood donations of $0.6 \%$ compared with the total of the whole blood donations [5].

In 2009, 60 whole blood donations were performed per 1,000 inhabitants [8] - a high number compared with that of the member states of the Council of Europe which amounts to a median of 36 whole blood donations per 1,000 inhabitants (quartile distance: 50-24) in 2006 [5]. During the same time 


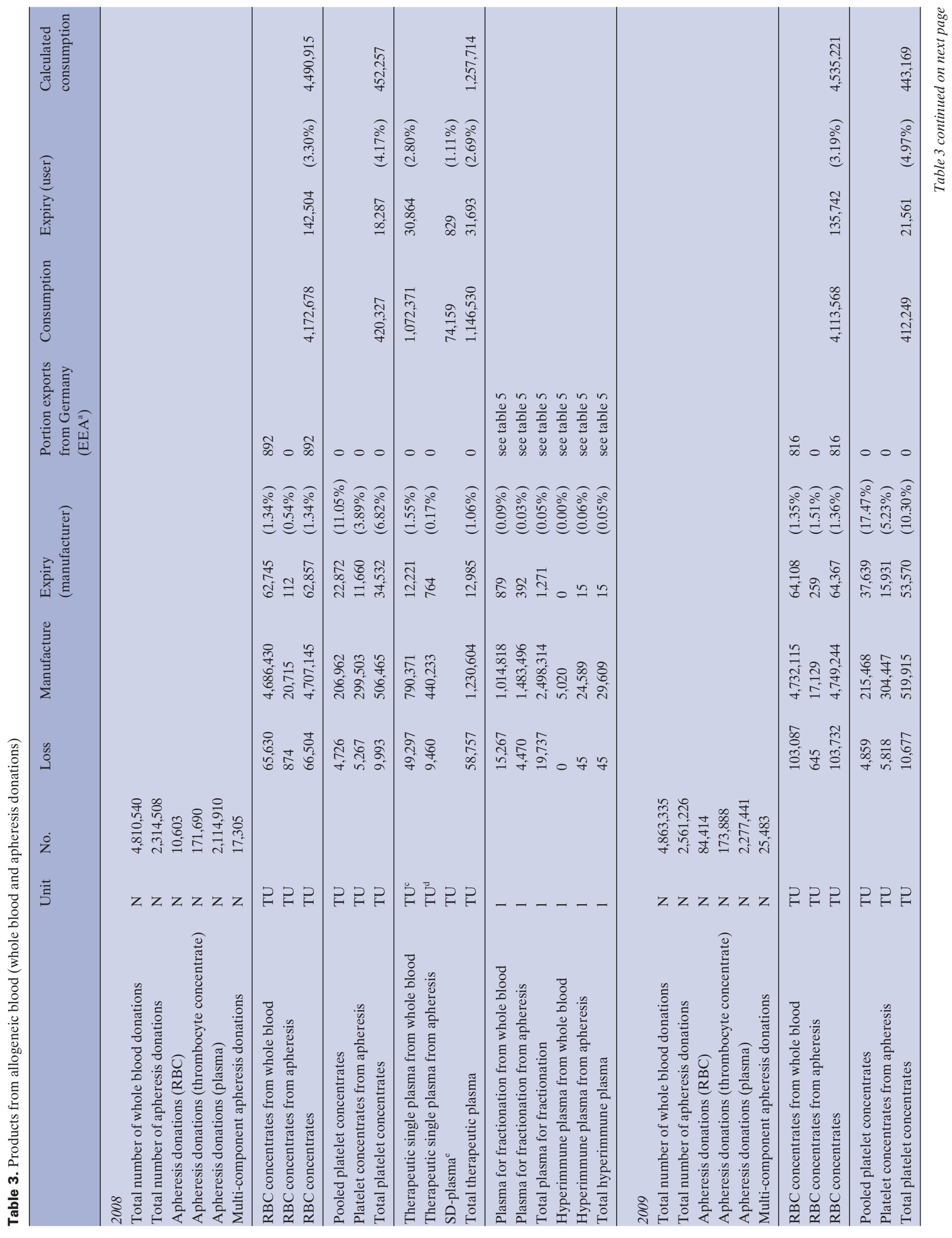




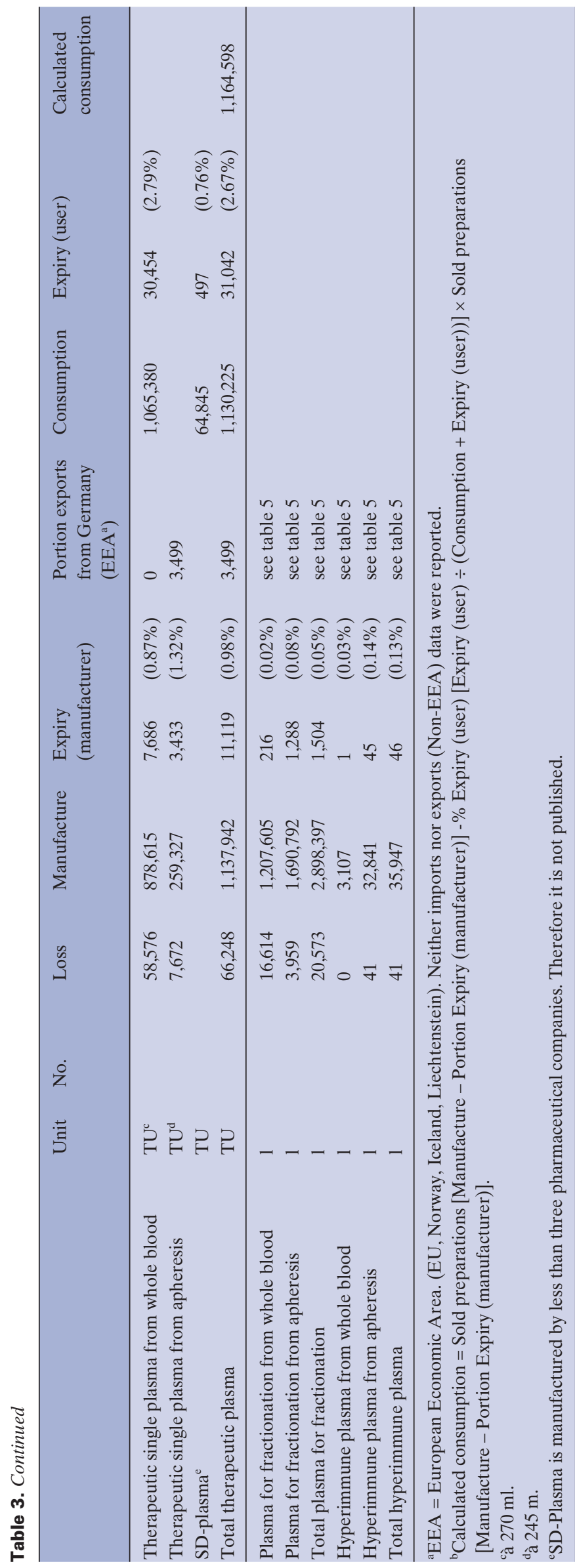

period, 58 whole blood donations per 1,000 inhabitants were collected in Germany and 49 in the USA $[6,19]$ (fig. 2).

The number of apheresis donations rose from 2005 to 2009 by $15 \%$ on average by year to 2.56 million, the highest level since 2000 (table 3, fig. 1). Unlike 2003, the year in which less whole blood donations were collected due to the dramatic increase in apheresis donation, this recent increase has no effect on the number of whole blood donations. Plasmapheresis donations constitute the major portion of apheresis donations; the collection of RBCs and platelets by means of apheresis only accounts for roughly $9 \%$ of all apheresis donations. More than $90 \%$ of all plasmas collected by means of apheresis are used for the manufacture of plasma proteins.

The effects of the demographic changes on the supply with blood products in Germany are currently being discussed intensively. According to calculations by the Federal Statistical Office, the German population will have declined by up to $15 \%$ by 2060 compared with 2008 . At the same time, a shift in the age structure will be experienced - the portion of old people in the overall population will rise markedly [7, 8]. Especially in those regions where the age structure is changing drastically, dramatic losses are expected in the supply with blood, while the demand is expected to rise [9].

In the Federal Republic of Germany as a whole, the number of whole blood donations rose by nearly $12 \%$ during the past 10 years although the number of individuals who have reached the minimum age required for donations [20] declined by around $2 \%$ [7]. This development can be understood if we take a look at the donor age groups. Thus, the number of 18- to 34-year-olds, the age group with the largest portion of first-time donors, declined by around $9 \%$ while the number of 35- to 54-year-olds, who accounted for a large portion of multiple donors, increased by $4 \%$ [7]. Donors in this age group play an important part in contributing to the provision of blood components [10]. At the same time, the number of over 65-year-olds, the age group about which it is assumed that they need the largest portion of blood components, rose by $23 \%$.

Intended steps to be taken such as a more liberal regulation of the upper age limit for donors are designed to moderate a possible downward trend. The course of the future development of donor availability remains to be seen. In Germany, the donor frequency can still be described as very high, also compared with our European neighbours where considerably less blood is donated.

\section{RBC Concentrates}

Altogether, 4.7 million transfusion units (TU) of RBC concentrates were produced each in 2008 and in 2009 (fig. 3). The major portion of these RBC concentrates originates from whole blood donations, while only $0.4 \%$ was produced from apheresis donations (table 3 ). With a portion of $72 \%$ of the RBC concentrates manufactured, the institutes of the German and Bavarian Red Cross continued to be the major man- 


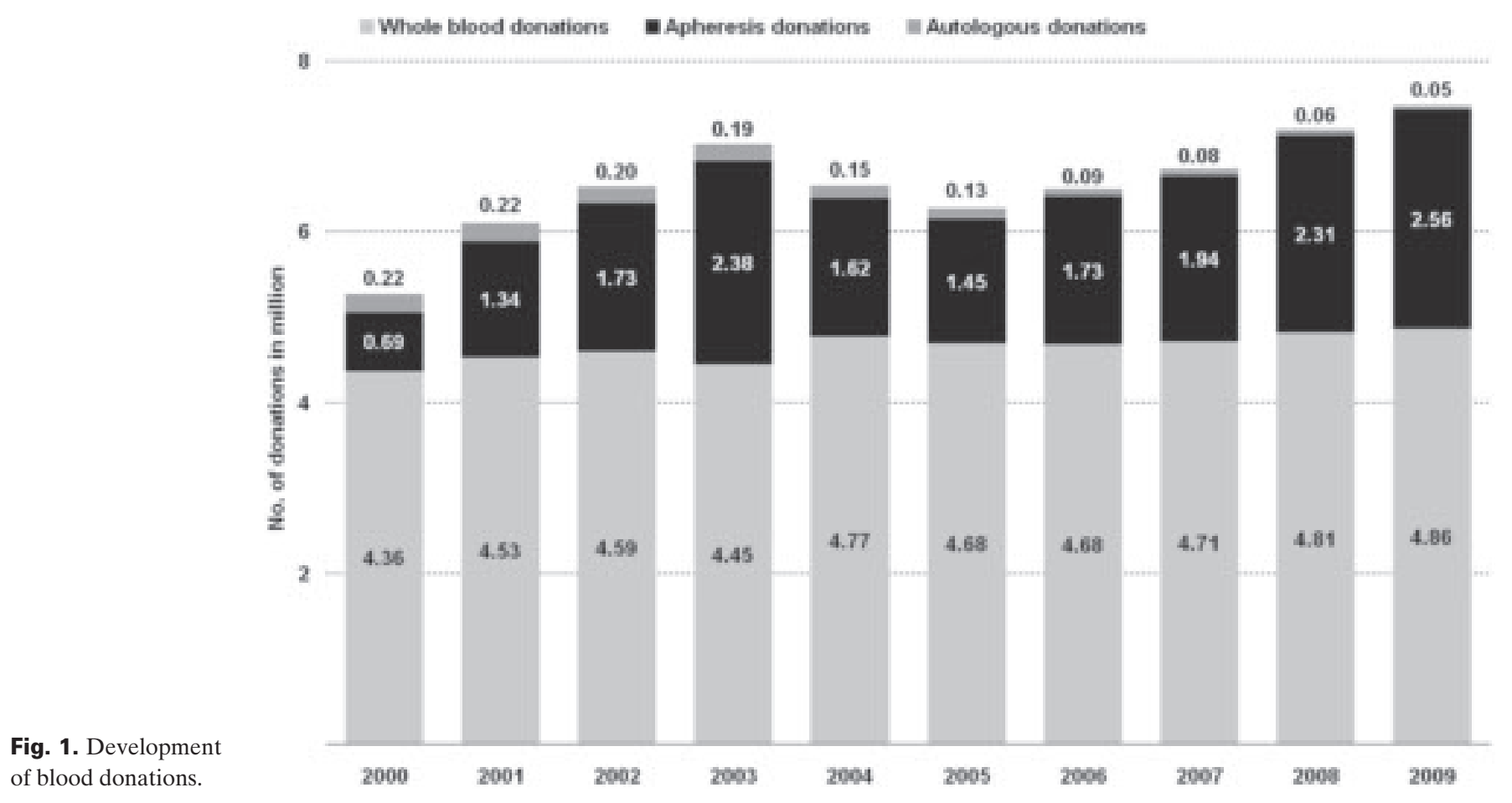

Fig. 2. Number of whole blood donations per 1,000 inhabitants in $2006[5,6]$.

80

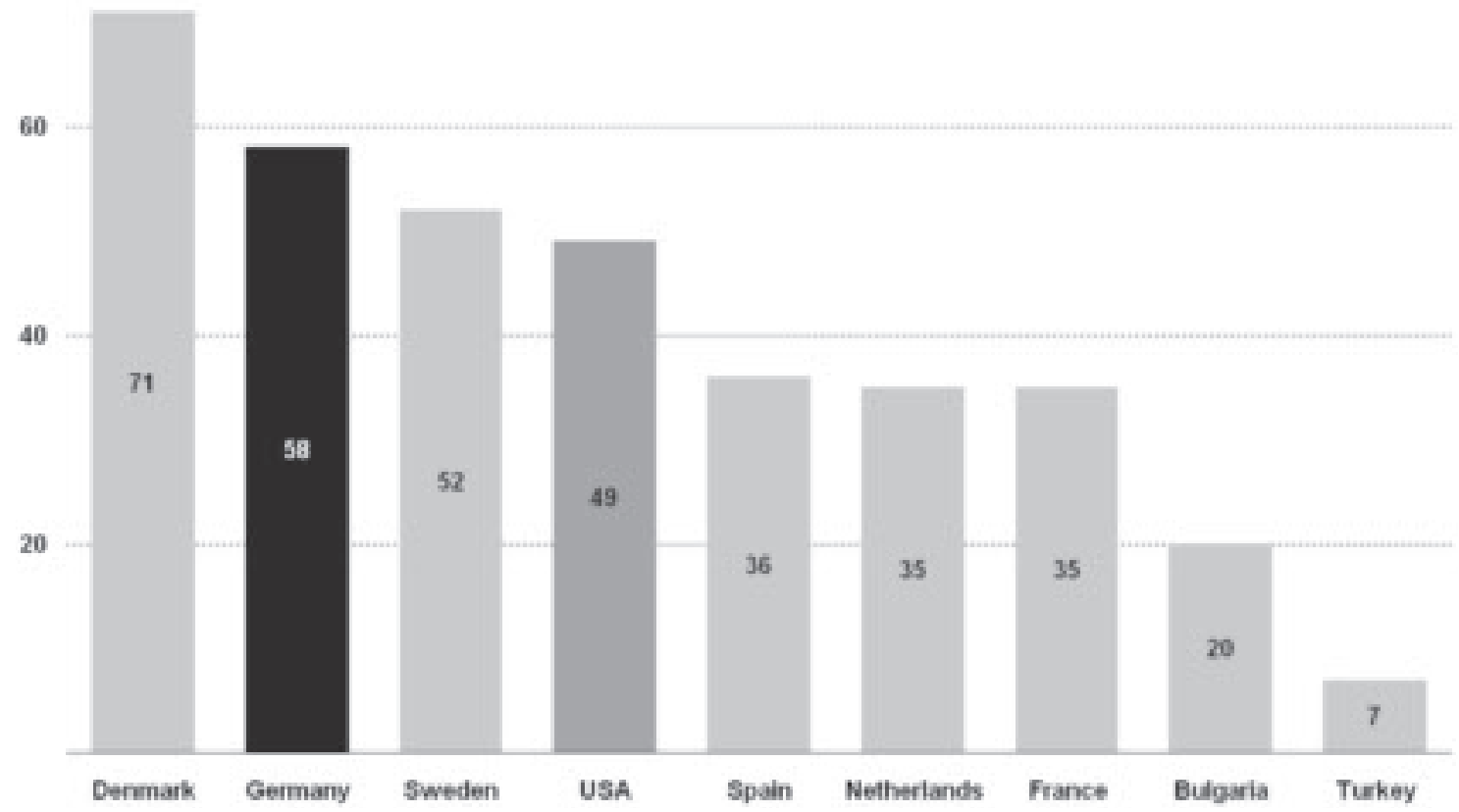

ufacturers, followed by the group of state, local authority, and other non-profit donor organisations as well as the facilities of private hospital operators with an unchanged portion of $20 \%$ over several years. The portion of private donor services rose continuously from $2.2 \%$ in 2000 to currently $7.5 \%$. The portion of RBC concentrates provided by the German Army for general use has remained constant with around $0.7 \%$.
Since 2004, the PEI also records the manufacture of irradiated RBC concentrates. The portion of these RBC concentrates compared with the over-all amount of RBC concentrates has risen from 3.2 to $4.0 \%$.

The already low number of RBCs from autologous blood donations, continued to decline. The rate for RBCs from autologous donations compared with the total supply of RBCs 
Table 4. Autologous blood and its components

\begin{tabular}{|c|c|c|c|c|c|c|c|c|}
\hline & Unit & No. & Manufacture & \multicolumn{2}{|c|}{$\begin{array}{l}\text { Portion expiry } \\
\text { (manufacturer) }\end{array}$} & Consumption & \multicolumn{2}{|c|}{ Expiry (user) } \\
\hline $\begin{array}{l}\text { Number of autologous blood collections } \\
\text { (whole blood) }\end{array}$ & $\mathrm{N}$ & 58,950 & & & & & & \\
\hline $\begin{array}{l}\text { Number of autologous blood collections } \\
\text { (apheresis) }\end{array}$ & $\mathrm{N}$ & 3,533 & & & & & & \\
\hline Total number of autologous blood collections & $\mathrm{N}$ & 62,483 & & & & & & \\
\hline Left as whole blood for transfusion & TU & & 12,390 & 917 & $(7.40 \%)$ & 6,280 & 6,879 & $(52.28 \%)$ \\
\hline RBC concentrates from whole blood & $\mathrm{TU}$ & & 42,747 & 2,055 & $(4.81 \%)$ & & & \\
\hline $\mathrm{RBC}$ concentrates from apheresis & $\mathrm{TU}$ & & 3,426 & 299 & $(8.73 \%)$ & & & \\
\hline Total RBC concentrates & TU & & 46,173 & 2,354 & $(5.10 \%)$ & 23,811 & 19,512 & $(45.04 \%)$ \\
\hline Platetet concentrates from whole blood & TU & & 402 & 1 & $(0.25 \%)$ & & & \\
\hline Platelet concentrates from apheresis & $\mathrm{TU}$ & & 11 & 0 & $(0.00 \%)$ & & & \\
\hline Total platelet concentrates & TU & & 413 & 1 & $(0.24 \%)$ & 171 & 90 & $(34.48 \%)$ \\
\hline Plasma from whole blood & TU & & 37,730 & 1,902 & $(5.04 \%)$ & & & \\
\hline Plasma from apheresis & TU & & 5,556 & 37 & $(0.67 \%)$ & & & \\
\hline Total plasma & TU & & 43,286 & 1,939 & $(4.48 \%)$ & 23,940 & 18,262 & $(43.27 \%)$ \\
\hline \multicolumn{9}{|l|}{2009} \\
\hline $\begin{array}{l}\text { Number of autologous blood collections } \\
\text { (whole blood) }\end{array}$ & $\mathrm{N}$ & 45,217 & & & & & & \\
\hline $\begin{array}{l}\text { Number of autologous blood collections } \\
\text { (apheresis) }\end{array}$ & $\mathrm{N}$ & 2,888 & & & & & & \\
\hline Total number of autologous blood collections & $\mathrm{N}$ & 48,105 & & & & & & \\
\hline Left as whole blood for transfusion & TU & & 7,912 & 727 & $(9.19 \%)$ & 3,909 & 4,949 & $(55.87 \%)$ \\
\hline RBC concentrates from whole blood & $\mathrm{TU}$ & & 35,059 & 1,962 & $(5.60 \%)$ & & & \\
\hline $\mathrm{RBC}$ concentrates from apheresis & TU & & 2,941 & 312 & $(10.61 \%)$ & & & \\
\hline Total RBC concentrates & $\mathrm{TU}$ & & 38,000 & 2,274 & $(5.98 \%)$ & 20,556 & 14,784 & $(41.83 \%)$ \\
\hline Platelet concentrates from whole blood & TU & & 406 & 1 & $(0.25 \%)$ & & & \\
\hline Platelet concentrates from apheresis & $\mathrm{TU}$ & & 43 & 0 & $(0.00 \%)$ & & & \\
\hline Total platelet concentrates & TU & & 449 & 1 & $(0.22 \%)$ & 185 & 11 & $(5.61 \%)$ \\
\hline Plasma from whole blood & TU & & 30,747 & 1,617 & $(5.26 \%)$ & & & \\
\hline Plasma from apheresis & TU & & 5,340 & 44 & $(0.82 \%)$ & & & \\
\hline Total plasma & TU & & 36,087 & 1,661 & $(4.60 \%)$ & 21,829 & 13,802 & $(38.74 \%)$ \\
\hline
\end{tabular}

decreased from $3.3 \%$ in 2000 to $0.7 \%$ in 2009 . With $44 \%$, the portion of expired autologous RBCs is markedly above that of allogeneic products. An even larger expiry rate was recorded for whole blood for transfusion from autologous blood donations - almost $60 \%$ in 2009 .

In 2008 and 2009, 978 and 977 RBC concentrates respectively were manufactured per 1,000 whole blood donations. Thus the best yield in the past 10 years could be obtained in 2008 with a loss before release of only $2.2 \%$.

The expiry rate of released RBCs in the donation services, too, continues to decrease and was below the level of previous years in 2009 with $1.36 \%$ (fig. 4). It has become clear that manufacturers have made major efforts to minimise the expiry rate for their products. Since the products required for quality and sterility controls must also be recorded as expiry, if they constitute released products, there is a lower limit of the expiry rate which cannot be exceeded. The latter has obviously been reached in the meantime.

Due to missing reports on the use of blood products from health care facilities, the approximate number of RBCs transfused was estimated on the basis of the products delivered by the donor services and the expiry figures reported by the users [11]. Based on this information, around 4.5 million RBC concentrates were transfused in 2008 and 2009, to an increasing extent also in an out-patient setting in panel doctor's practices and day clinics. While the portion of transfusions of RBC concentrates in these facilities was $4.6 \%$ in 2004 , it rose to $7.9 \%$ in 2009 .

Since no reports on expiry figures were available from a part of the facilities performing $\mathrm{RBC}$ transfusions, the portion 
Fig. 3. RBC concentrates from allogeneic blood: portions accounted for by the manufacturers.

\section{in Private donation certres}

- State-run and non-profit limited liability donation services, donations services at muricipal or private hospitals, donation services of the German Army

Elood donation services of the Red Cross
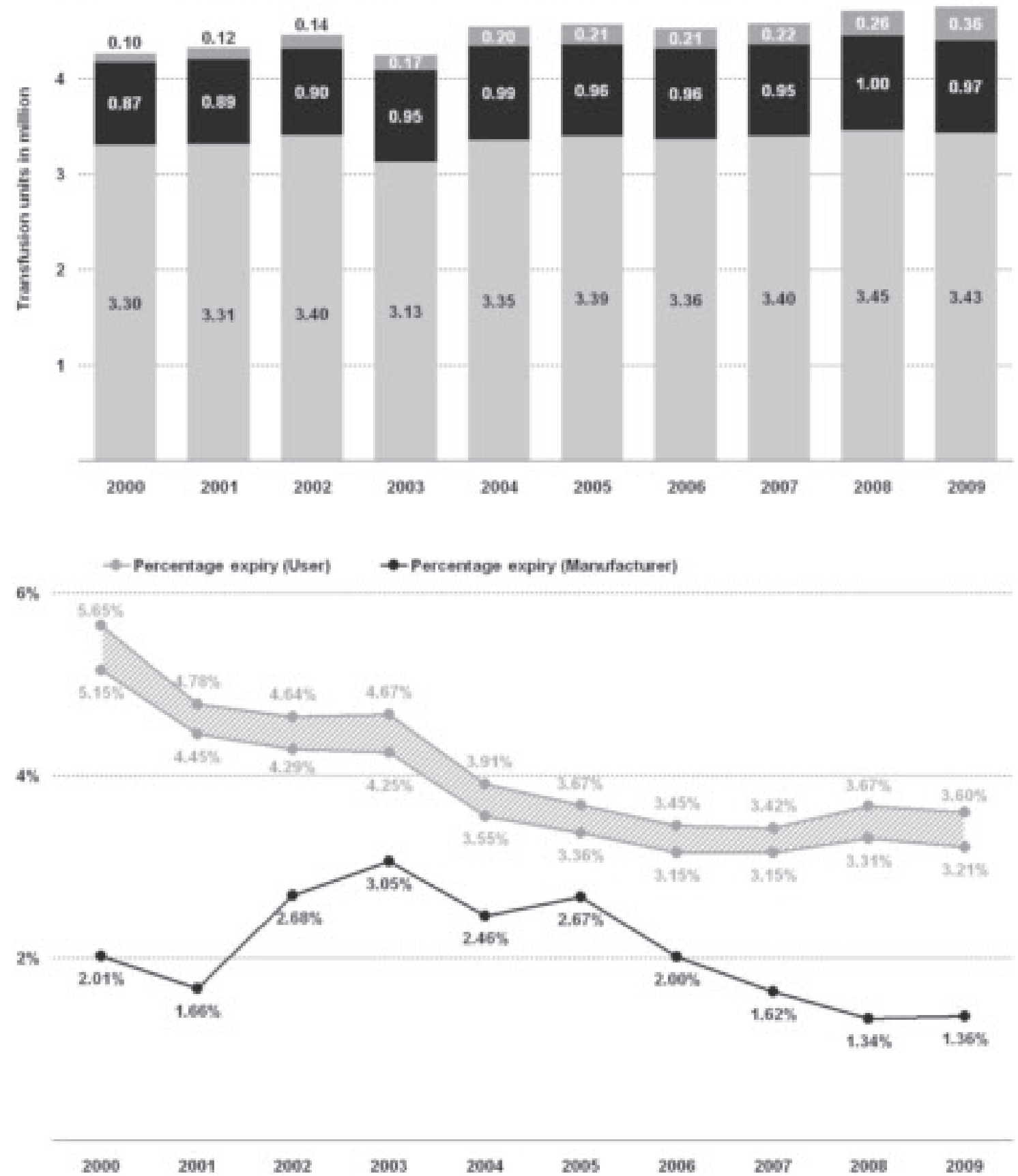

Fig. 4. $\mathrm{RBC}$ concen trates from allogeneic blood: portions reported from expired $\mathrm{RBC}$ concentrates at the manufactureres and users. Hashed area: the lower limit describes the expiry rate reported, the upper limit describes the corrected expiry rate (see explanations in the text).
The supply level of RBC concentrates for the German population can still be considered as good, with 58 per 1,000 inhabitants, above all compared with the member states of the Council of Europe. The median of these countries was 36 RBC concentrates per 1,000 inhabitants in 2006 (quartile distance: 48-29). The figure of 2006 in Germany was 55 [5]. Detailed studies of the supply of RBC concentrates have shown that the supply can fluctuate by up to $20 \%$ during one given 


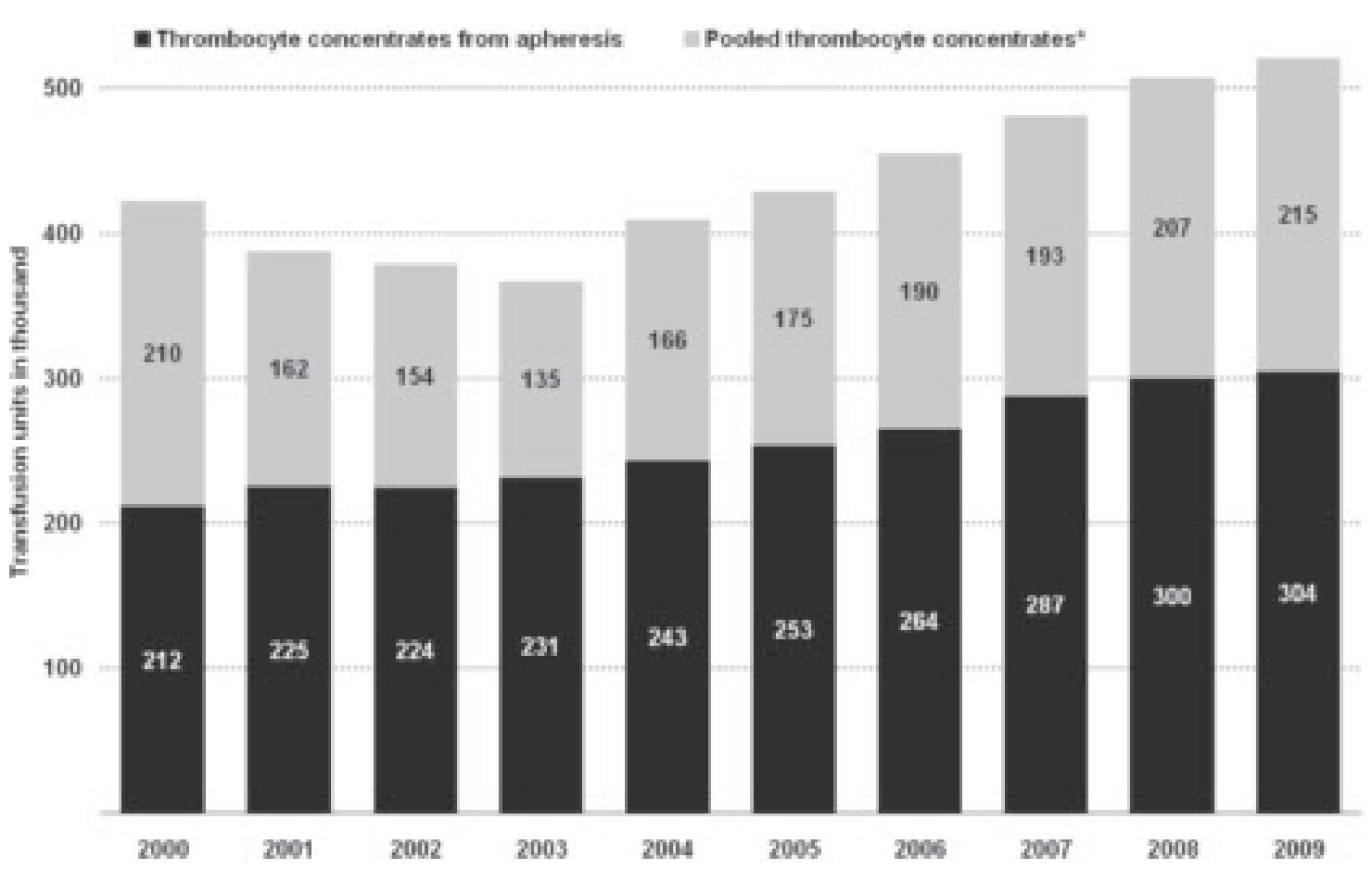

Fig. 6. Platelet concentrates from allogeneic blood: portions reported for expired platelet concentrates in $\%$ at the manufacturers and users. Hashed area: The lower limit describes the expiry rate reported, the upper limit the corrected expiry rate (see explanations in the text).

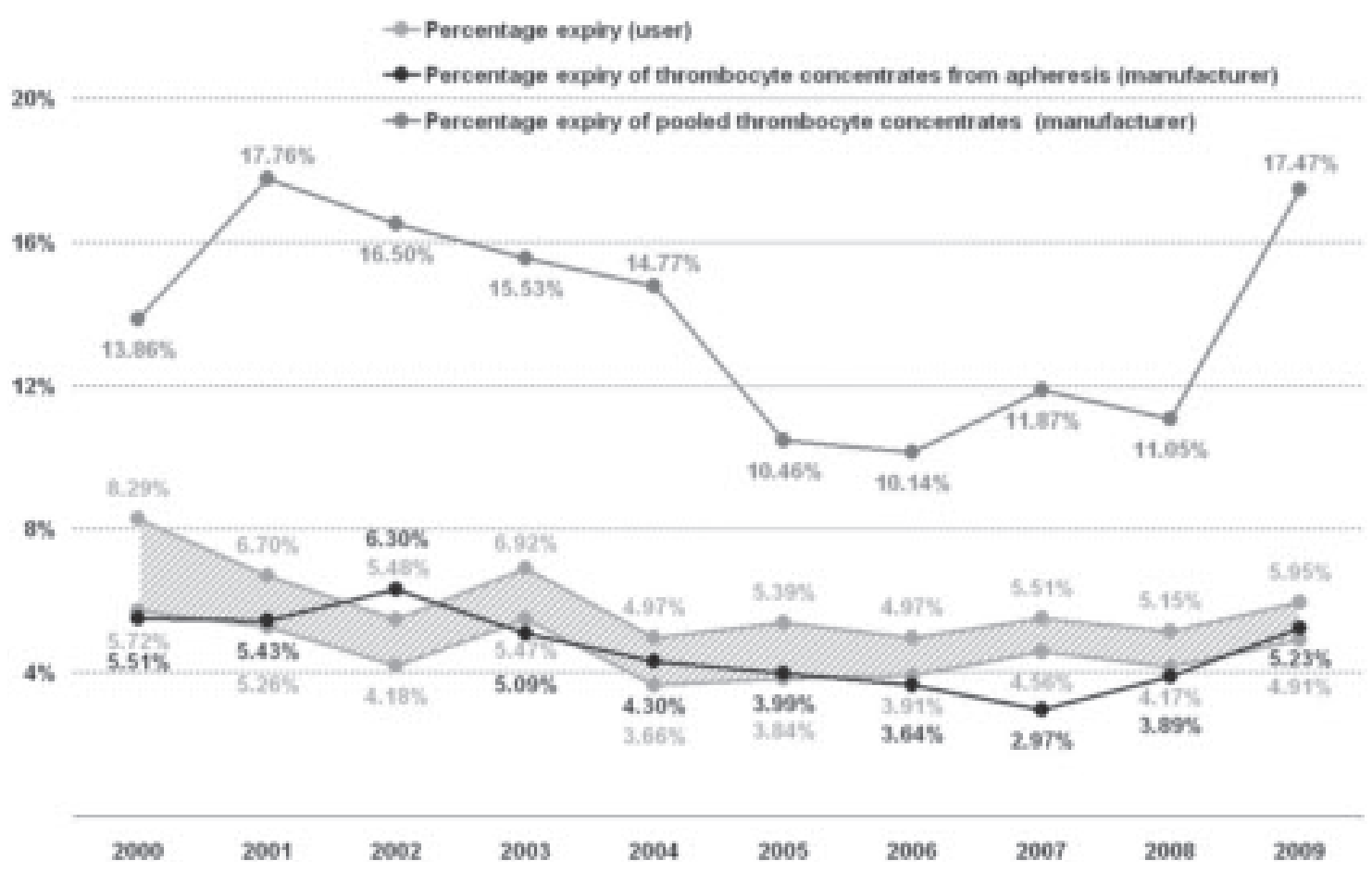

year [12]. Health care facilities are obviously able to overcome temporary bottle necks in the supply by prioritising and appropriate planning.

\section{Platelet Concentrates}

The favourable trend for the manufacturing figures of platelet concentrates continued in 2009, with 520,000 platelet concen- trates released for transfusion, even though the annual increase has in the meantime become smaller.

The portions accounted for by the different types of manufacture have remained unchanged. Around $60 \%$ of the platelet concentrates are manufactured by means of apheresis. One apheresis procedure produces 1.8 platelet concentrates on average. Pooled platelet concentrates are manufactured from 


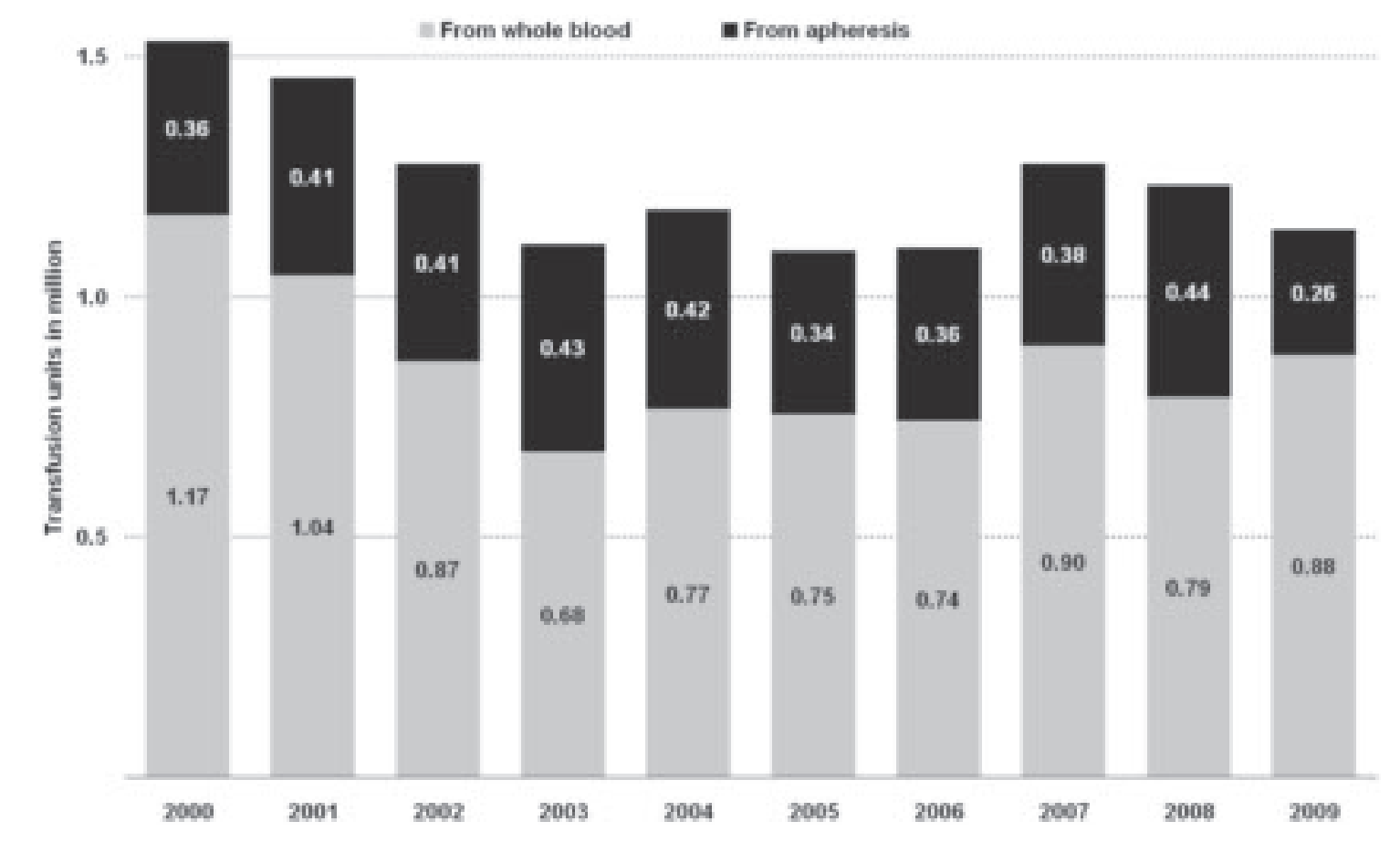

Fig. 7. Therapeutic single plasma from allogeneic blood: portions of manufacture from whole blood and apheresis.

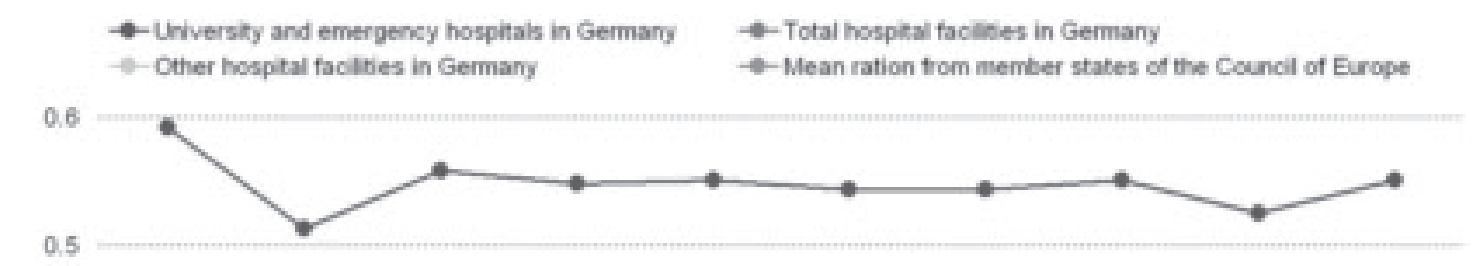

Fig. 8. Ratio of transfused plasmas compared with transfused RBCs (plasma/RBC ratio): The black lines refer to facilities in Germany; the grey line refers to the medium plasma/RBC ratio of member states of the Council of Europe.

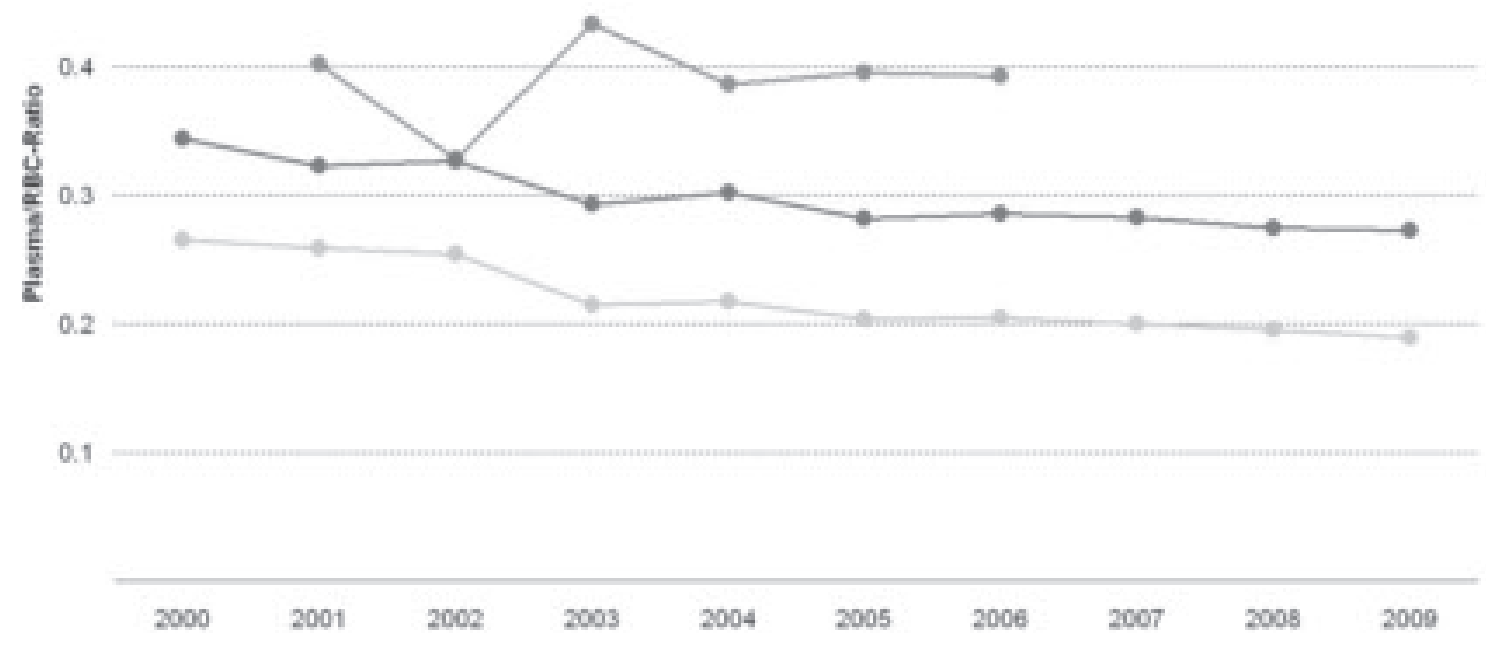

around $18 \%$ of the whole blood donations (table 3, fig. 5). The portion of irradiated platelet concentrates rose from $30 \%$ in 2004 to $34 \%$ in 2009 .

While, from 2002 to 2007, the expiry rate at the manufacturers has decreased steadily, it rose in 2008 slightly and increased in 2009 clearly. In this context, attention has to be paid to a major difference between pooled and apheresis platelet concentrates. While the expiry rate for apheresis platelet concentrates moderately increased again after its low of $3 \%$ in 2007 , with $1 \%$ per annum, it increased for pooled platelet concentrates from below 12 to $17 \%$. The reason for the increase in the expiry rate - above all for pooled platelet concentrates - could be explained by the fact that a cut in the shelf life of 1 day was recommended in Opinion 38 in 2008 


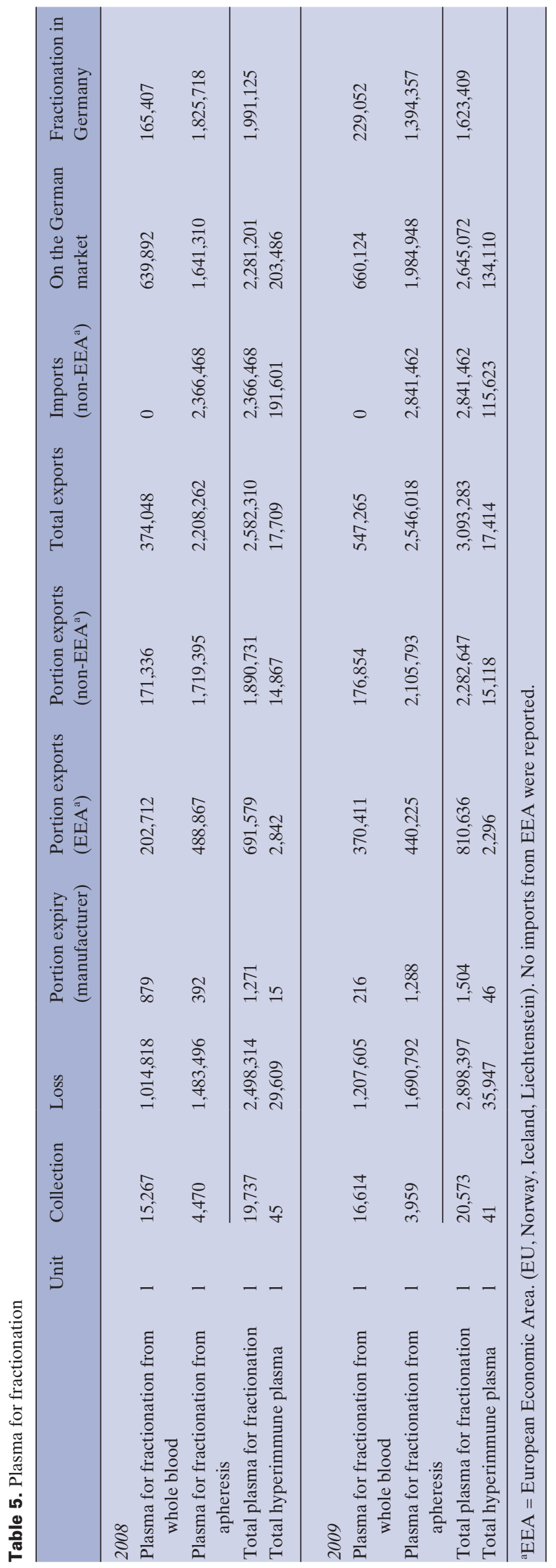

[13] together with a possibly stagnating demand for these products (table 3 , fig. 6). Apheresis platelet concentrates are supplied in a highly demand-orientated manner so that accordingly, almost all these products are transfused. Compared with this, an increased quantity of pooled platelet concentrates has obviously been manufactured for stock-piling purposes to balance out any possible bottlenecks caused by the cut in the shelf-life, which, however, could not be transfused due to lack of demand and expired as a consequence. In 2009, for the first time after 6 years, fewer products were transfused compared with the previous year (table 3). Whether or not this high expiry rate will again decrease in the next few years, thanks to the change in manufacturing management and distribution logistics, remains to be seen.

\section{Plasma for Transfusion}

After 2007 when the largest therapeutic plasma quantity of the last 7 years was manufactured, the manufacture decreased again to 1.1 million units in 2009 (table 3, fig. 7). In 2009, a graduated plan came into force designed to reduce the risk of transfusion-related acute lung injury (TRALI). This graduated plan bans the marketing of untested plasma of women with a history of pregnancy [14]. There was no risk of a bottleneck, since, among other things, shortages can be mitigated by targeted plasmapheresis from male donors. Figures provide proof that no bottlenecks occurred after the graduated plan relating to TRALI was implemented. Amazingly enough, with $23 \%$, the portion of plasma for transfusion manufactured from apheresis even dropped to its lowest level so far observed. The quantity of plasma produced from whole blood rose both for therapeutic plasma and for plasma for fractionation. At the same time, the quantity of plasma for fractionation produced from plasmapheresis also increased (fig 7 and 9).

Thanks to the long shelf-life of therapeutic plasma, the expiry rate is lower than for the more perishable cellular blood components. From 2000 to 2009, the mean expiry rate at the manufacturers was $1.6 \%$ with a markedly lower expiry rate reported for 2009 amounting to only $0.6 \%$. The mean expiry rate at the users was $3.0 \%$ of the quantity distributed for transfusion purposes. Expiry of SD plasma at the users was clearly below that figure with a mean rate of $1.1 \%$.

An indicator in the reports of the Council of Europe for the national use of blood component is the ratio of the plasma units transfused over the RBCs transfused (plasma/RBC ratio). According to these reports, between 2001 and 2006 the mean for Europe was one TU plasma per 2.5 RBC concentrates $($ plasma $/ \mathrm{RBC}$ ratio $=0.39)$. In Germany, the ratio was below the mean for Europe throughout this period with values between 3.7 and 2.9 transfused RBC concentrates per plasma unit (plasma/RBC ratio $0.27-0.34$ ). Whereas the ratio calculated for Germany has decreased markedly in the past 10 years, no general trend could be observed for Europe. This statement is based on the plasma/RBC ratio calculated from 


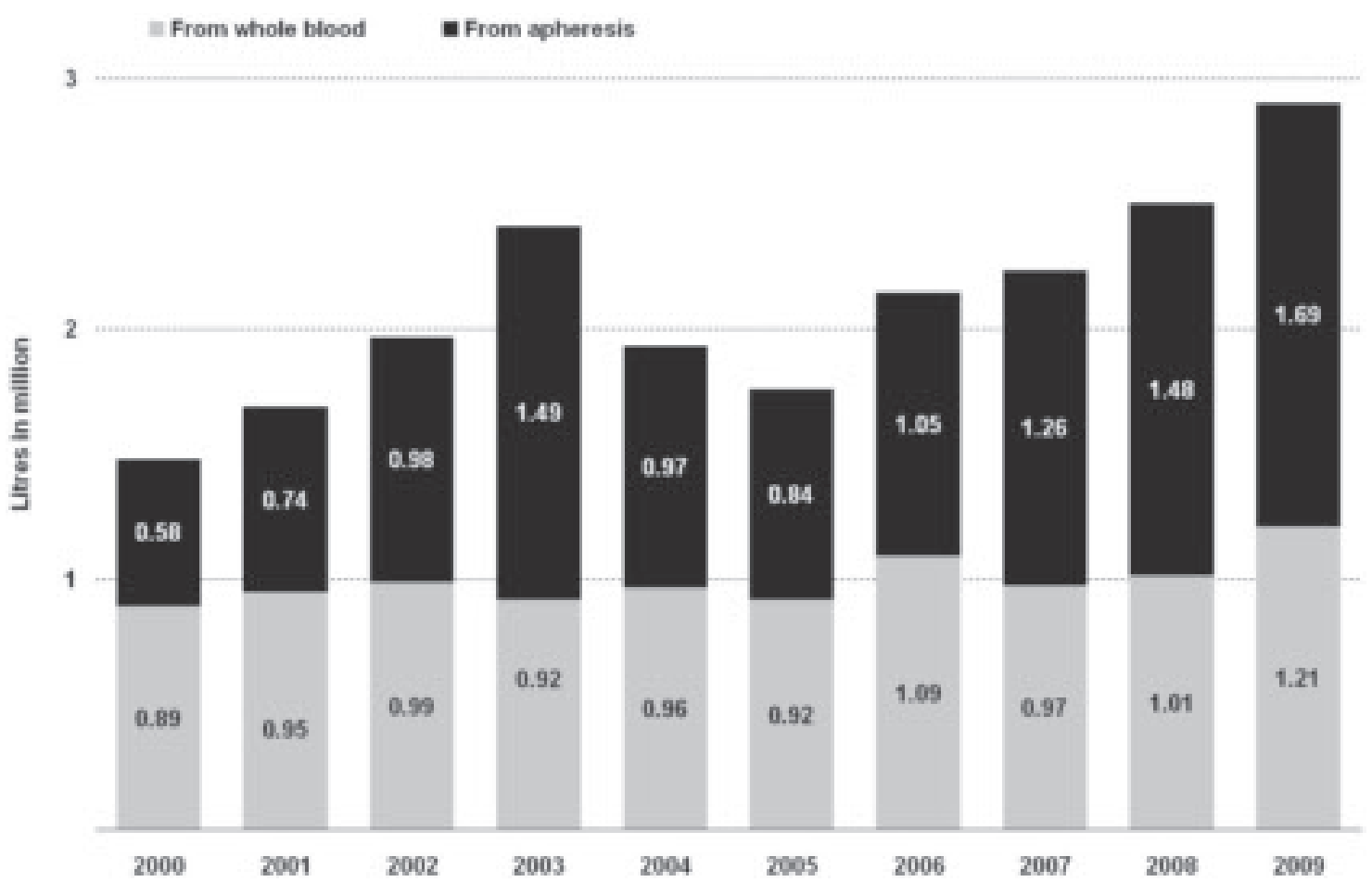

the total of all units reported as transfused in a given country (fig. 8).

If, however, the consumption by university and traumatology hospitals, which care for trauma patients with massive bleeding, is compared with that of 'other' health care facilities and hospitals in general, a dramatic difference is observed. Conforming to the recommendations of the cross section guidelines for the treatment with blood components and plasma derivatives [15], the pro rata plasma consumption has decreased in the major part of the 'other' facilities from one TU plasma per approximately $3.7 \mathrm{RBC}$ concentrates in 2000 (plasma/RBC ratio $=0.27$ ) to one TU plasma per $5.3 \mathrm{RBC}$ concentrates in 2009 (plasma/RBC ratio $=0.19$ ). The ratio at university and accident hospitals has remained nearly unchanged ever since 2001 with on average one TU plasma transfused per $1.8 \mathrm{RBC}$ concentrates (plasma/ $\mathrm{RBC}$ ratio $=$ $0.55)$. This shows that a restrictive use of plasma in the treatment of excessive bleeding is obviously considered not to be appropriate. This phenomenon is also highlighted by studies of patients with massive transfusion requirements. Here, a lower mortality rate was observed if the plasma/RBC ratio for the transfusion was $\geq 0.6$ [16]. Current recommendations from traumatologists on the portion of plasma in massive transfusions are in line with these observations [17]. The difference in plasma/RBC ratios between the group comprising university and traumatology hospitals and that comprising all other health care facilities performing transfusions is significant for all the years observed (Mann-Whitney U test $\mathrm{p}<0.05)$. Here, it becomes apparent that an undifferentiated consideration of the plasma/RBC ratio disregards important facts (fig. 8).

\section{Plasma for Fractionation}

The collection of plasma as a starting material for the manufacture of plasma proteins continued to increase in Germany. For the first time in 2008, the 2.5 million 1 limit was reached equivalent to an increase of $12 \%$ compared with the previous year. A further increase in the quantity of plasma for fractionation by $16 \%$ to 2.9 million 1 could be recorded in $2009 ; 58 \%$ of this quantity originates from plasmapheresis (table 5, fig. 9). The total quantity collected is equivalent to 35.51 per 1,000 inhabitants. In the member states of the Council of Europe, the median collection in 2006 was 51 (quartile distance 14-2) per 1,000 inhabitants; the figure for Germany was 261 for the same year [5].

These increases are almost entirely brought about by private plasmapheresis centres. These facilities were able to more than double their production since 2005. In addition, the donation services of the Red Cross were able to step up their collection of plasma for fractionation by $17 \%$, while the collection levels accounted for by state, local authority, and other non-profit-making donor services together with the facilities of private hospital operators and the German Army more or less remained at the level of 2007. Private plasmapheresis centres by now contribute $61 \%$ to the total quantity collected. $33 \%$ are contributed by the Red Cross and $6 \%$ by other donor services (fig. 10).

Germany is the number one supplier of plasma for fractionation in Europe. In 2006, around 50\% of the stock reported from Europe was produced in Germany [5]. Reported figures from the past 2 years show the very complexity of international trade with this raw material, indicating 


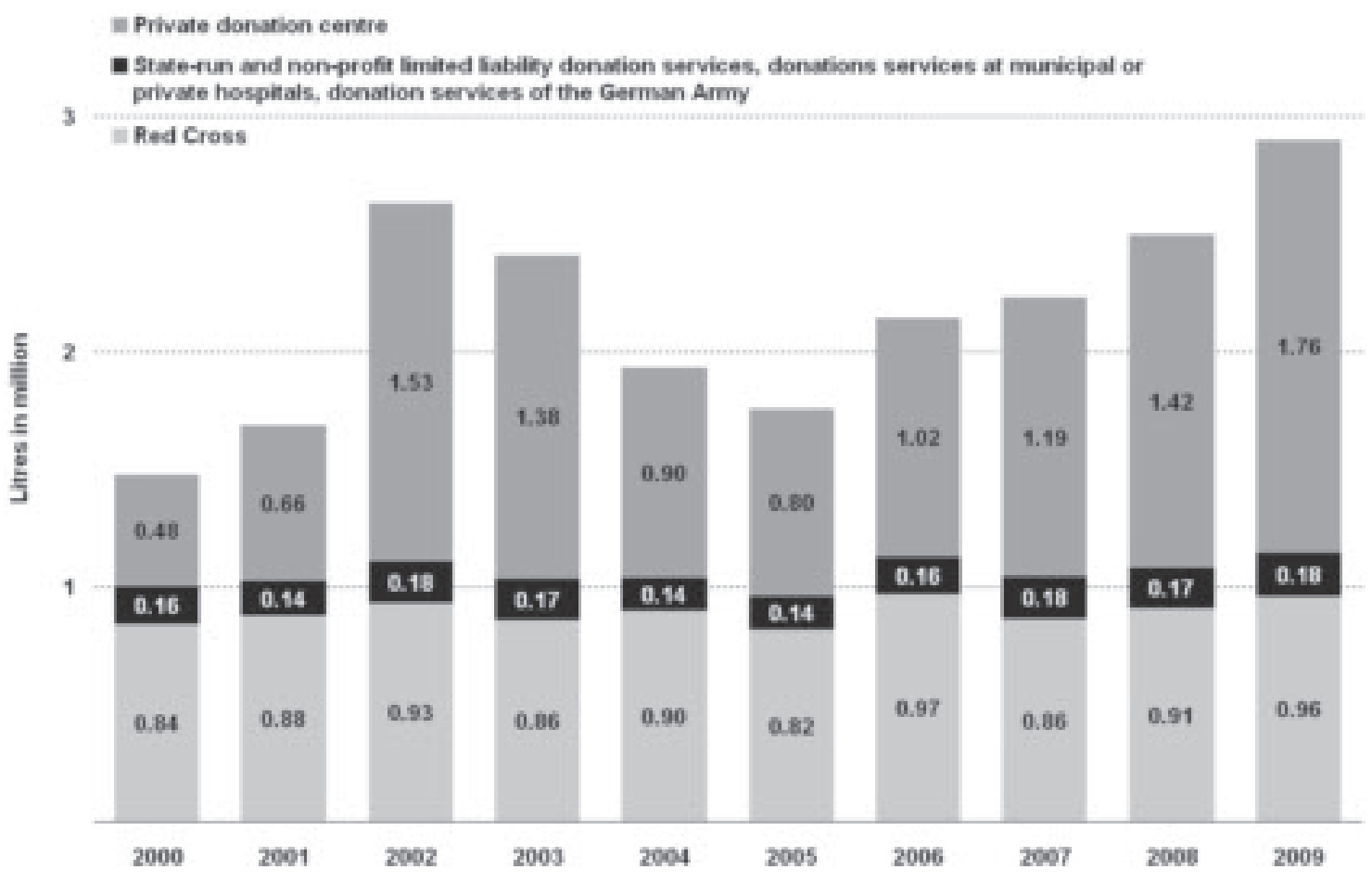

Fig. 10. Plasma for fractionation: portions of manufacturers compared with the total supply.

Fig. 11. Plasma for fractionation: collection as well as the quantity available and the quantity manufactured in Germany.

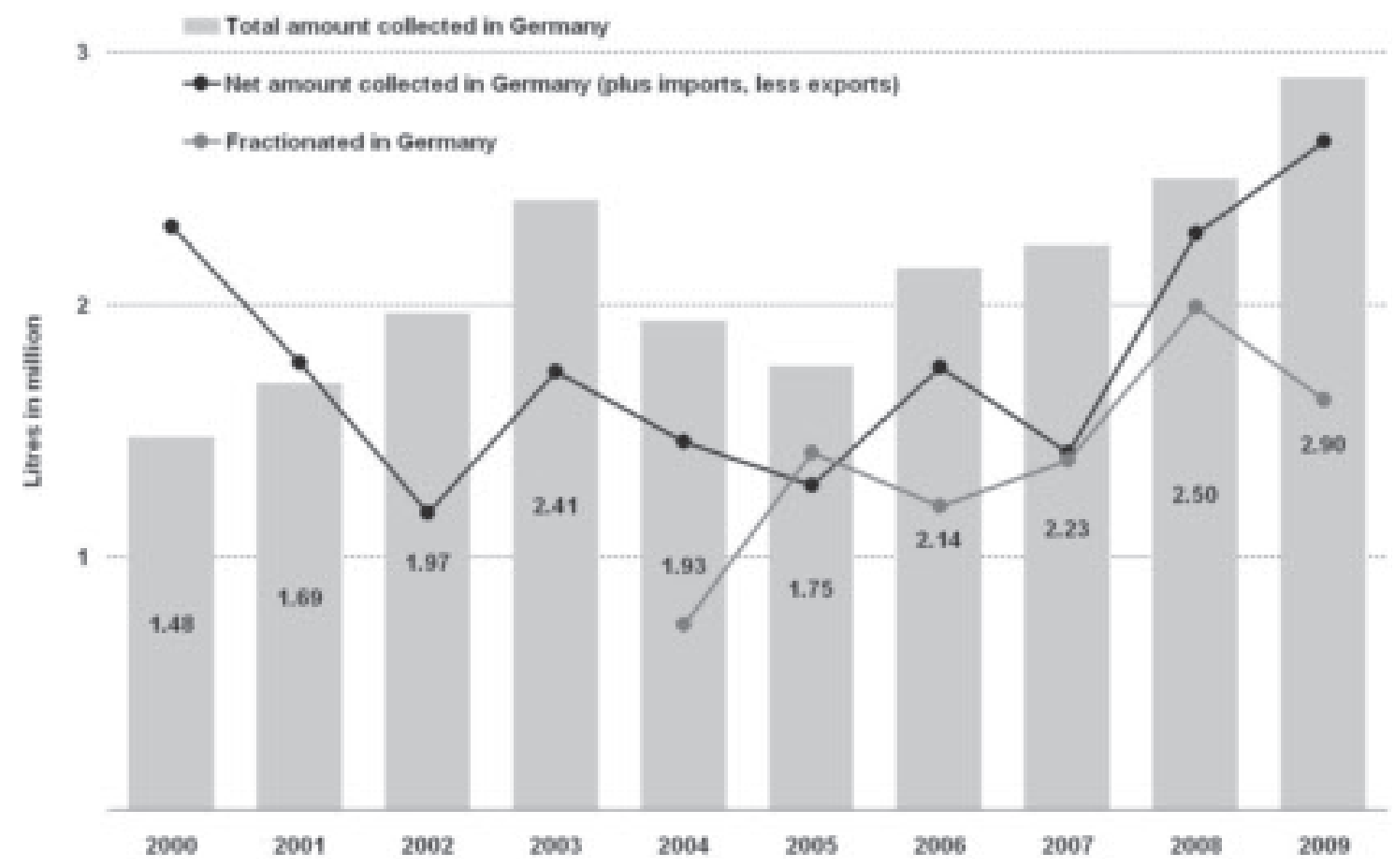

that the quantities of imported and exported plasma for fractionation produced in Germany were approximately equivalent. The net quantity available on the German market amounted to around 2.3 million 1 in 2008 and 2.6 million 1 in 2009 equivalent to around $91 \%$ of the quantity produced in Germany. In 2007, the net quantity available in Germany was almost entirely used for further processing in Germany.
In the subsequent years, the portion of plasma fractionated in Germany decreased to $61 \%$ (table 5, fig. 11). Arithmetically, there is a remainder of 1 million 1 for 2009 for which no explanation can be made. Such residual quantities could also be observed in previous years [11]. The quantity totalled as from 2004 suggests that there should be stocks in Germany of 2.5 million 1 . 


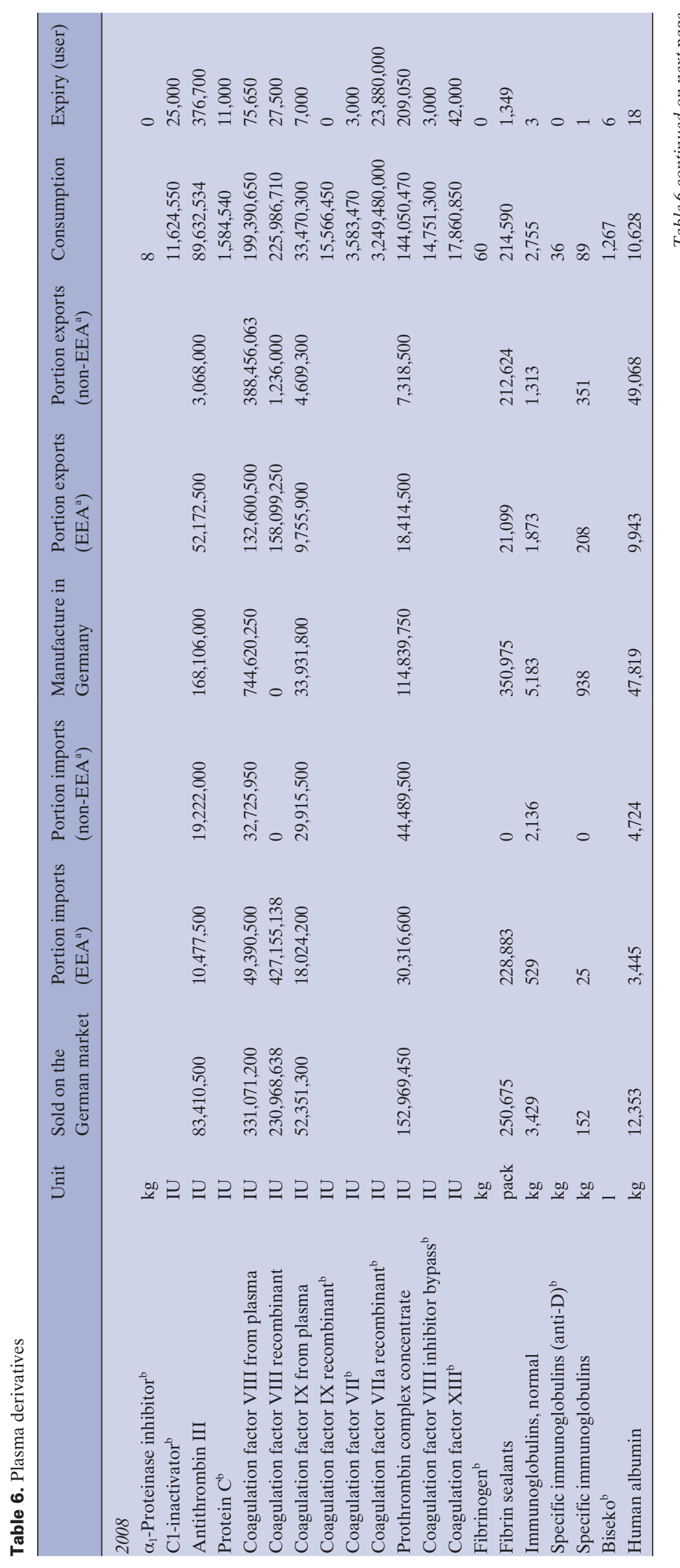




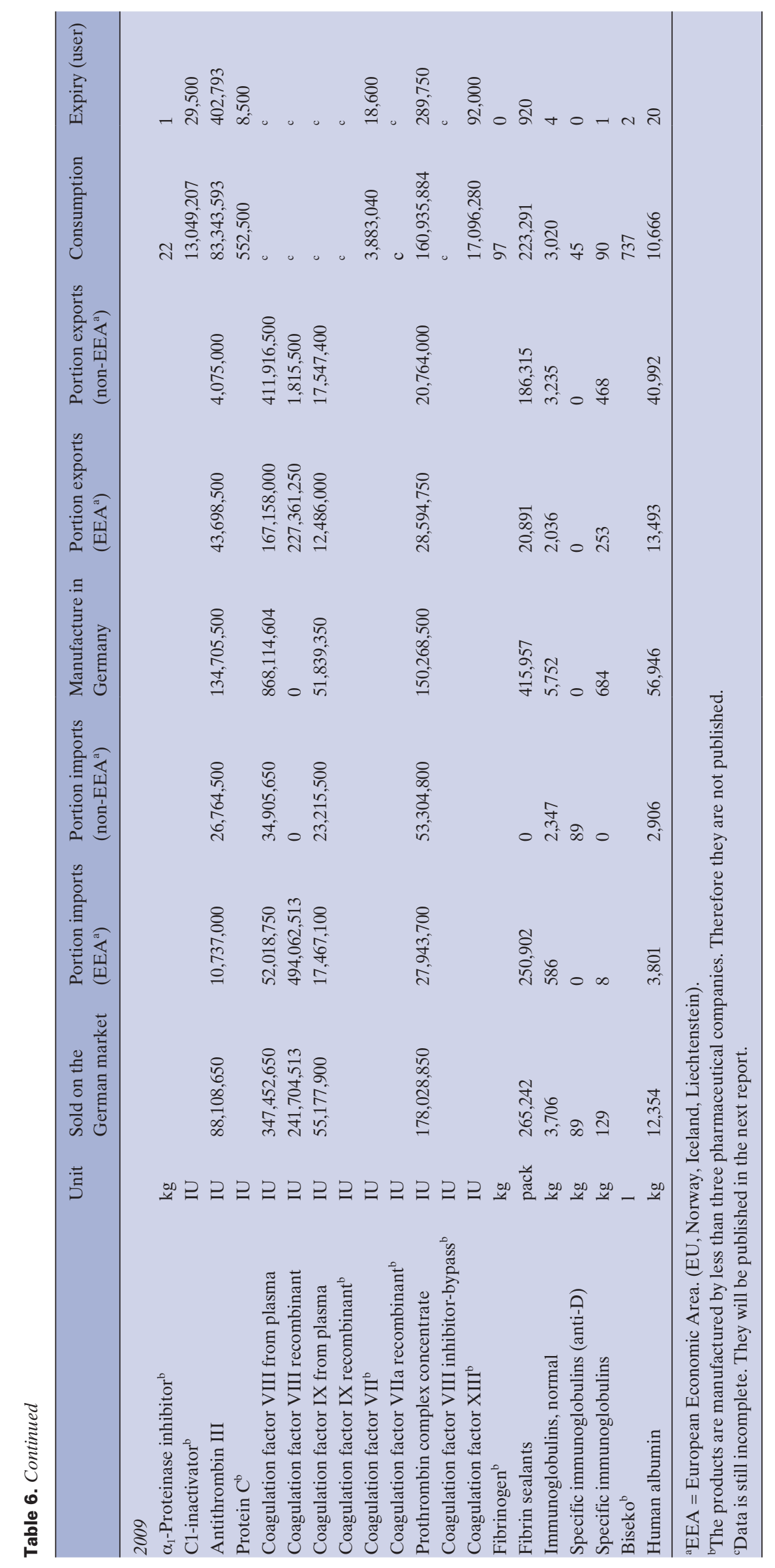


Table 7. Haematopoietic stem cells from peripheral blood

Table 8. Haematopoietic stem cells from cord blood

\begin{tabular}{|c|c|c|c|c|c|c|}
\hline & \multirow[t]{2}{*}{ Unit } & \multicolumn{2}{|l|}{2008} & \multicolumn{3}{|l|}{2009} \\
\hline & & autologous & allogeneic & autologous & $\begin{array}{l}\text { allogeneic, } \\
\text { related }\end{array}$ & $\begin{array}{l}\text { allogeneic, } \\
\text { unrelated }\end{array}$ \\
\hline Total of separations & $\mathrm{N}$ & 5,796 & 5,111 & 5,775 & 961 & 4,603 \\
\hline Donors & $\mathrm{N}$ & 3,795 & 4,218 & 3,576 & 725 & 3,957 \\
\hline Manufacture & TXU & 7,496 & 4,948 & 6,815 & 865 & 4,421 \\
\hline Portion expiry (manufacturer) & TXU & 54 & 9 & 134 & 3 & 0 \\
\hline Portion exports (EEA) & TXU & 0 & 1,162 & 0 & 1 & 1,766 \\
\hline Portion exports (non-EEA) & TXU & 1 & 885 & 0 & 0 & 1,202 \\
\hline Imports (EEA) & TXU & 0 & 396 & 3 & 0 & 78 \\
\hline Imports (non-EEA) & TXU & 0 & 95 & 0 & 0 & 75 \\
\hline Loss (manufacturer) & TXU & 24 & 3 & 63 & 1 & 0 \\
\hline Number of patients transplanted in Germany & $\mathrm{N}$ & 2,584 & 1759 & 2,714 & 619 & 1,312 \\
\hline Number of transplants & $\mathrm{N}$ & 3,272 & 1,918 & 3,177 & 686 & 1,410 \\
\hline
\end{tabular}

EEA = European Economic Area. (EU, Norway, Iceland, Liechtenstein); TXU = individual dose for a transplant which can consist of several apheresis donations/bags.

\begin{tabular}{|c|c|c|c|c|c|c|}
\hline & \multirow[t]{2}{*}{ Unit } & \multicolumn{2}{|l|}{2008} & \multicolumn{3}{|l|}{2009} \\
\hline & & autologous & allogeneic & autologous & $\begin{array}{l}\text { allogeneic, } \\
\text { related }\end{array}$ & $\begin{array}{l}\text { allogeneic, } \\
\text { unrelated }\end{array}$ \\
\hline Manufacture & TXU & 8,793 & 2,528 & 9,575 & 17 & 3,289 \\
\hline Portion exports (EEA) & TXU & 0 & 69 & 0 & 0 & 75 \\
\hline Portion exports (non-EEA) & TXU & 0 & 56 & 0 & 0 & 55 \\
\hline Imports (EEA) & TXU & 0 & 7 & 0 & 0 & 9 \\
\hline Imports (non-EEA) & TXU & 0 & 6 & 0 & 0 & 6 \\
\hline Loss (manufacturer) & TXU & 478 & 2,513 & 596 & 0 & 3,217 \\
\hline Number of patients transplanted in Germany & $\mathrm{N}$ & 0 & 20 & 0 & 3 & 18 \\
\hline Number of transplants & $\mathrm{N}$ & 0 & 24 & 0 & 3 & 24 \\
\hline
\end{tabular}

EEA = European Economic Area. (EU, Norway, Iceland, Liechtenstein); TXU = individual dose for a transplant which can consist of several apheresis donations/bags.

Table 9. Haematopoietic stem cells from marrow

\begin{tabular}{|c|c|c|c|c|}
\hline & \multirow[t]{2}{*}{ Unit } & \multicolumn{3}{|l|}{2009} \\
\hline & & autologous & $\begin{array}{l}\text { allogeneic, } \\
\text { related }\end{array}$ & $\begin{array}{l}\text { allogeneic, } \\
\text { unrelated }\end{array}$ \\
\hline Donations & $\mathrm{N}$ & 17 & 100 & 822 \\
\hline Donors & $\mathrm{N}$ & 17 & 88 & 820 \\
\hline Manufacture & TXU & 19 & 97 & 843 \\
\hline Portion expiry (manufacturer) & TXU & 0 & 0 & 0 \\
\hline Portion exports (EEA) & TXU & 0 & 0 & 226 \\
\hline Portion exports (non-EEA) & TXU & 0 & 0 & 187 \\
\hline Imports (EEA) & TXU & 0 & 0 & 25 \\
\hline Imports (non-EEA) & TXU & 0 & 0 & 9 \\
\hline Loss (manufacturer) & TXU & 0 & 1 & 0 \\
\hline Number of patients transplanted in Germany & $\mathrm{N}$ & 4 & 114 & 131 \\
\hline Number of transplants & $\mathrm{N}$ & 4 & 117 & 134 \\
\hline
\end{tabular}

EEA = European Economic Area. (EU, Norway, Iceland, Liechtenstein); TXU = individual dose for a transplant which can consist of several apheresis donations/bags. 


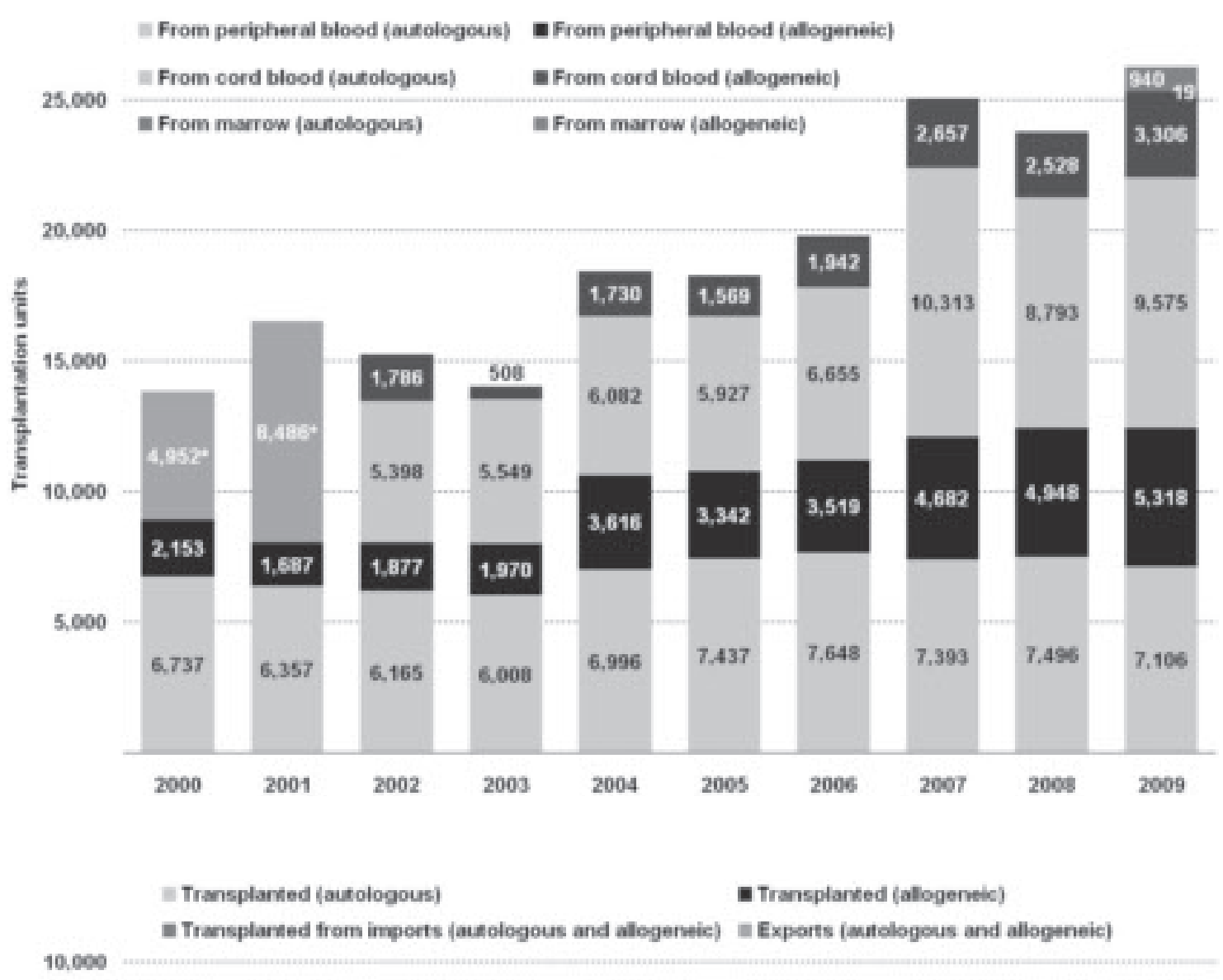

Fig. 12. Haematopoietic stem cells: manufacture from peripheral blood, cord blood, and bone marrow. *Up to 2001 , no distinction was made between autologous and allogeneic stem cell preparations from cord blood. Figures are given in transplantation units $(\mathrm{TXU})=$ individual dose for one transplant, which may consist of several bags.

Fig. 13. Haematopoietic stem cells: transplantations. Black: Stem cells transplanted in Germany; Grey: Exported stem cells, i.e. stem cells transplanted outside Germany. Figures are given in transplantation units $(\mathrm{TXU})=$ individual dose for one transplant, which may consist of several bags.

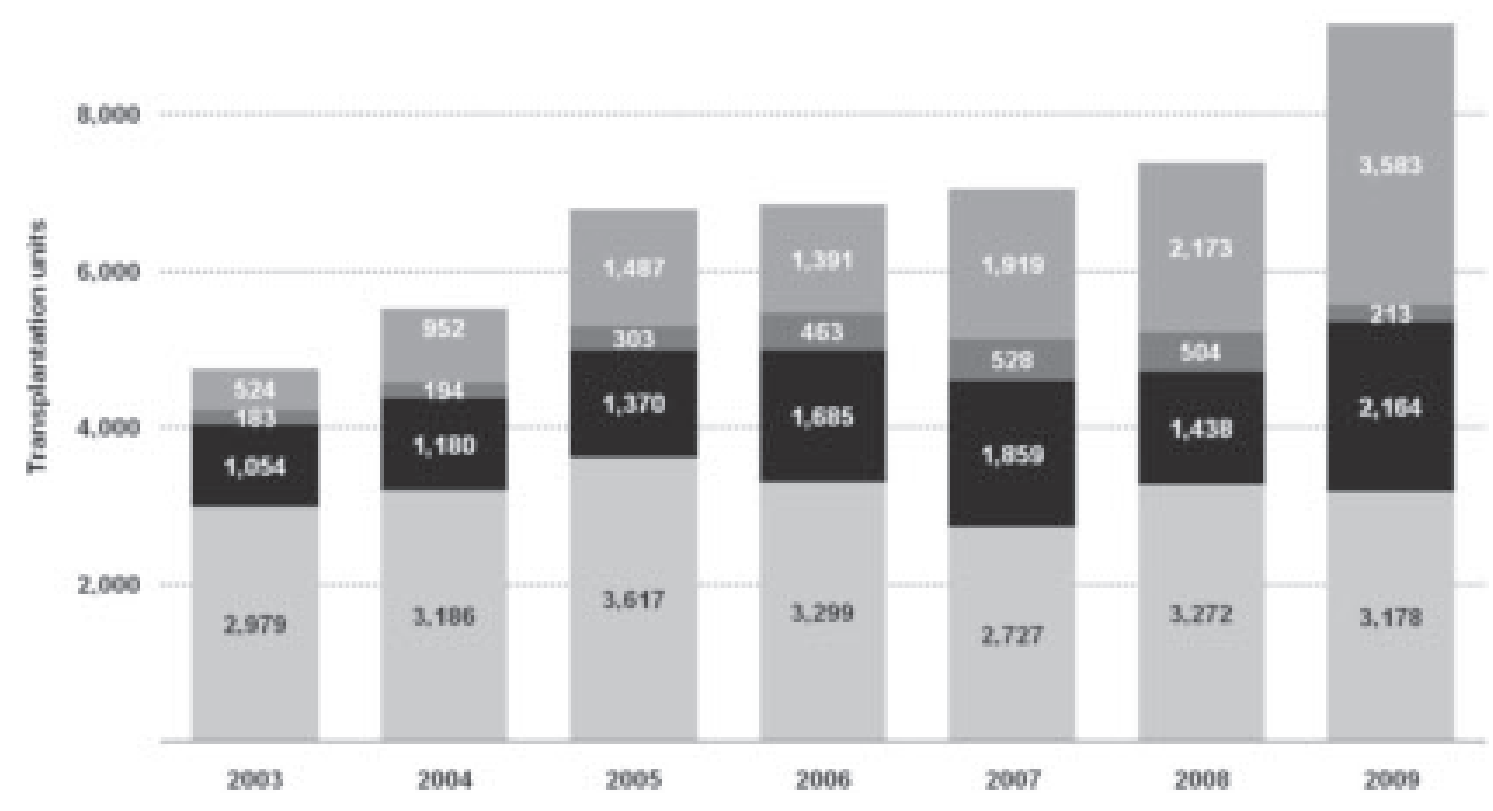

\section{Plasma Proteins}

In Germany, there is still no shortage of plasma proteins. Although plasma is available as starting material in large quantities, some products are not manufactured in Germany; however, the demand is satisfied thanks to the import of these products. In this context, the supply is rather greater than the demand for a major part of these products. The median per-

centage portion of the supply reported in relation to the quantity sold in Germany was $80 \%$ (quartile distance: $87-63 \%$ ) in 2009 (table 6).

\section{Haematopoietic Stem Cells}

The number of stem cell preparations manufactured in Germany amounts to roughly 25,000 transplantation units (TXU). 
Autologous stem cells from cord blood account for the largest portion with around $37 \%$ (table 8 ), followed by autologous stem cells from peripheral blood with $26 \%$ (table 7 ). Haematopoietic stem cells from bone marrow which have been notifiable preparations since 2007 pursuant to Section 8d, paragraph 3 German Transplantation Act (Transplantationsgesetz; TPG) [18] were recorded by means of online reporting pursuant to Section 21 TFG for the first time in 2009 because of the contextual relation to the Transfusion Act. Haematopoietic stem cells from bone marrow form the smallest group with a portion of roughly $4 \%$ (table 9 , fig. 12 ).

The greatest increase can be recorded for autologous haematopoietic stem cells from cord blood. The number of TXU manufactured annually has risen by 77\% compared with 2002 . None of these preparations has been transplanted up to now. The manufacture of allogeneic haematopoietic stem cells from cord blood has risen sharply since 2002, and has nearly doubled in 2009. These products have been transplanted in relatively small numbers: 24 in 2008 and 27 in 2009 - just below $1 \%$ of the products manufactured (table 8 ).

On the other hand, in 2009, in relation to the total transplants manufactured from peripheral blood, the portion transplanted in Germany was $47 \%$ for autologous products and
$40 \%$ for allogeneic products. More than $50 \%$ of the manufactured allogeneic stem cell products were exported. Based on the assumption that these products, too, were $100 \%$ transplanted, the transplantation rate has risen to even $96 \%$. These figures show that the greatest significance is currently attached to the transplantation of haematopoietic stem cells from peripheral blood (table 7).

Germany is increasingly becoming an exporter for allogeneic stem cell transplants. In 2003, the portion exported was still $21 \%$, while in $2009,35 \%$ of the products manufactured were exported. The portion of imported transplants, on the other hand, is negligible (fig. 12, 13).

\section{Acknowledgement}

The authors gratefully acknowledge the translation of the report by Mrs. C. Taylor, Paul-Ehrlich-Institut.

\section{Disclosure}

The authors declared that no conflict of interest exists.

\section{References}

1 Gesetz zur Regelung des Transfusionswesens (Transfusionsgesetz - TFG) in der Fassung der Bekanntmachung vom 28. August 2007. Bundesgesetzblatt 2007 Teil I 45:2169-2177.

2 Paul-Ehrlich-Institut: Reports on Blood Supply in Compliance with the German Transfusion Act. www.pei.de/bloodsupply.

3 Paul-Ehrlich-Institut: The German Haemophilia Registry. www.pei.de/dhr-en.

4 Votum 1 des Arbeitskreises Blut des Bundesministeriums für Gesundheit. Aufwandsentschädigung für Blut- und Plasmaspender. Bundesgesundheitsbl Gesundheitsforsch Gesundheitsschutz 1993;12:542.

5 van der Poel C, Janssen M P, Borkent-Raven B The Collection, Testing and Use of Blood and Blood Products in Europe in 2006, Council of Europe Publishing 2009.

6 US Department of Health and Human Services: The 2007 National Blood Collection and Utilization Survey. 2008. www.aabb.org/programs/biovigilance/ nbcus/Documents/07nbcusrpt.pdf.

7 Tabellen des Statistischen Bundesamts Deutschland zum Bevölkerungsstand. www.destatis.de.

8 Statistisches Bundesamt (Hrsg): 12. koordinierte Bevölkerungsvorausberechnung, Begleitmaterial zur Pressekonferenz Pressemitteilung Nr. 435 vom 18.11.2009.

9 Greinacher A, Fendrich K, Alpen U, Hoffmann W: Impact of demographic changes on the blood supply: Mecklenburg-West Pomerania as a model region for Europe. Transfusion 2007;47:395-401.
10 Ritter S, Willand L, Reinhard B, Offergeld R, Hamouda O: Blutspenderpopulationen in Deutschland: Demographie und Spendeaktivität. Bundesgesundheitsbl Gesundheitsforsch Gesundheitsschutz 2008;51:915-925.

11 Henseler O Heiden M, Haschberger B, Hesse J, Seitz R: Report on Notifications Pursuant to $\$ 21$ German Transfusion Act for 2007. Transfus Med Hemother 2010;37:29-47.

12 Kamp C Heiden M, Henseler O, Seitz R: Management of blood supplies during an influenza pandemic. Transfusion 2010;50:231-239.

13 Votum 38 des Arbeitskreises Blut des Bundesministeriums für Gesundheit: Festlegung der Haltbarkeitsfrist von Thrombozytenkonzentraten mit dem Ziel der Reduktion lebensbedrohlicher septischer Transfusionsreaktionen durch bakterielle Kontamination. Bundesgesundheitsbl Gesundheitsforsch Gesundheitsschutz 2008;51:1484.

14 Bekanntmachung über die Zulassung von Arzneimitteln - Abwehr von Arzneimittelrisiken - Anordnung von Auflagen zu den Zulassungen von therapeutischem Einzelplasma (in Quarantäne gelagertes oder mit einem Verfahren zur Pathogeninaktivierung behandeltes Plasma). Bundesanzeiger 2009;84:2064-2065.
15 The Board of the German Medical Association on the Recommendation of the Scientific Advisory Board: Cross-Sectional Guidelines for Therapy with Blood Components and Plasma Derivatives. Transfus Med Hemother 2009;36(6)..

16 Sperry JL, Ochoa JB, Gunn SR, Alarcon LH, Minei JP, Cuschieri J, Rosengart MR, Maier RV, Billiar TR, Peitzman AB, Moore EE: An FFP:PRBC transfusion ratio $>/=1: 1.5$ is associated with a lower risk of mortality after massive transfusion. J Trauma 2008;65:986-993.

17 Pär I, Johansson PI, Stensballe J: Hemostatic resuscitation for massive bleeding: the paradigm of plasma and platelets - a review of the current literature. Transfusion 2009;50:701-710.

18 Gesetz über die Spende, Entnahme und Übertragung von Organen und Geweben (Transplantationsgesetz - TPG) in der Fassung der Bekanntmachung vom 4. September 2007. Bundesgesetzblatt Teil I 2007;46:2206-2220.

19 Statistiken des U.S. Census Bureau (2010). www. census.gov.

20 Bundesministerium der Justiz (Hrsg): Bekanntmachung der Richtlinien zur Gewinnung von Blut und Blutbestandteilen und zur Anwendung von Blutprodukten (Hämotherapie) gemäß $\S 12$ und 18 des Transfusionsgesetzes (TFG) (Änderungen und Ergänzungen 2010), Bundesanzeiger 2010:101a. 